\title{
Unraveling the Roles of Regulatory Genes during Domestication of Cultivated Camellia: Evidence and Insights from Comparative and Evolutionary Genomics
}

\author{
Chao Yan ${ }^{1,2,3,+}$, Ping Lin ${ }^{1,2,+}+$, Tao Lyu ${ }^{1,2,4}$, Zhikang Hu ${ }^{1,2}$, Zhengqi Fan ${ }^{1,2}$, Xinlei Li ${ }^{1,2}$, \\ Xiaohua Yao ${ }^{1,2}$, Jiyuan $\mathrm{Li}^{1,2}$ and Hengfu Yin 1,2,*D \\ 1 State Key Laboratory of Tree Genetics and Breeding, Research Institute of Subtropical Forestry, Chinese \\ Academy of Forestry, Hangzhou 311400, Zhejiang, China; yanc01@163.com (C.Y.); linping80@126.com (P.L.); \\ taolyu1@163.com (T.L.); huzhikang01@163.com (Z.H.); fanzhengqi_risf@outlook.com (Z.F.); \\ lixinlei_risf@outlook.com (X.L.); yaoxh168@163.com (X.Y.); lijiyuan_risf@outlook.com (J.L.) \\ 2 Key Laboratory of Forest Genetics and Breeding, Research Institute of Subtropical Forestry, \\ Chinese Academy of Forestry, Hangzhou 311400, Zhejiang, China \\ 3 Experimental Center for Subtropical Forestry, Chinese Academy of Forestry, Fenyi 336600, Jiangxi, China \\ 4 College of Marine Sciences, Ningbo University, Ningbo 315211, Zhejiang, China \\ * Correspondence: hfyin@caf.ac.cn; Tel.: +86-571-6310-5093 \\ + These authors have contributed equally to this work.
}

Received: 26 August 2018; Accepted: 5 October 2018; Published: 10 October 2018

\begin{abstract}
With the increasing power of DNA sequencing, the genomics-based approach is becoming a promising resolution to dissect the molecular mechanism of domestication of complex traits in trees. Genus Camellia possesses rich resources with a substantial value for producing beverage, ornaments, edible oil and more. Currently, a vast number of genetic and genomic research studies in Camellia plants have emerged and provided an unprecedented opportunity to expedite the molecular breeding program. In this paper, we summarize the recent advances of gene expression and genomic resources in Camellia species and focus on identifying genes related to key economic traits such as flower and fruit development and stress tolerances. We investigate the genetic alterations and genomic impacts under different selection programs in closely related species. We discuss future directions of integrating large-scale population and quantitative genetics and multiple omics to identify key candidates to accelerate the breeding process. We propose that future work of exploiting the genomic data can provide insights related to the targets of domestication during breeding and the evolution of natural trait adaptations in genus Camellia.
\end{abstract}

Keywords: domestication; genomics; Camellia; transcription factors; quantitative trait locus; genome-wide association study; fruit development

\section{Introduction}

Domestication of wild plants has resulted in substantial phenotypic changes related to molecular changes of key regulatory genes. Understanding the genetic basis of domestication can provide insights into the mechanism of rapid evolution of traits influenced by human demands. Using forward genetics, researchers have identified many important genes contributing to various processes relevant to plant development and growth in several crop species. In addition, to achieve some human desirable traits, mutations of homologous genes in different plants have occurred [1,2]. For instance, the domestication of the loss of seed shattering in sorghum is found to be controlled by mutations of 
a YABBY transcription factor [3] and the modifications of orthologs in rice and maize were revealed to be involved in shattering domestication [3]. Therefore, convergent selection of gene alleles related to important regulators provides a promising insight into revealing the trait domestication in different selection programs of plants [4,5].

However, in perennial woody plants, the approach from phenotypes to genetic modification is merely successful due to the long breeding cycles and inbreeding depression. Recent advances in genomics have facilitated the unraveling of the evolution history and selection signatures of cultivated tree crops. In fruit trees, genome sequencing, and re-sequencing have provided essential evidence of genomic signatures of domestication such as gene family expansion, genomic diversity, genome selective sweep and more [6-9]. In a recent study, combined analyses of large-scale re-sequencing and transcriptomics in pears have led to the identification of valuable candidate genes underlying fruit quality [10]. Therefore, the genome sequencing and global expression analyses in tree plants provide a useful means for understanding how traits are domesticated and how they have evolved.

The genus Camellia includes more than 250 species and is the largest genus in the plant family Theaceae [11,12]. Camellia species are generally evergreen shrubs or small trees and most of them originate from Southeastern Asia. A majority of these species is native to China. Despite the disagreements of different taxonomic systems, cultivars of wild Camellia species are currently known all over the world. In Camellia plants, the human selection of favorable traits such as leaf metabolism, floral development, and seed oil content has resulted in substantial genetic alterations in commonly-seen cultivars when compared to their wild ancestors. The understanding of the genetic and genomic characteristics under the breeding process is of great significance for dissecting trait evolution and domestication to facilitate Camellia breeding.

In recent years, the breakthrough of DNA sequencing technology has greatly expedited the basic research of understanding the molecular domestication process in Camellias. Progress in generating high-quality and in-depth genomics databases were made in Camellia plants. Particularly, two reference genomes of tea trees were released $[13,14]$, which could facilitate the future research in unraveling the mechanisms of evolution and domestication of Camellia plants. A number of RNA-sequencing (RNA-seq) studies were reported in several wild and cultivated Camellia plants. In this review, we aim to provide a timely summarization of advances in genomic and genetic studies of large-scale gene expression profiling (Table 1). We go over recent progresses of genomics research in Camellia plants and focus on pathways related to traits with significant economic values. We survey the studies utilizing high-throughput sequencing technology for investigating global gene expression profiling, small RNA identification, and other types of protein coding and noncoding genes. We also pay a close look at the field of population genetics approaches in Camellia plants including the genome-wide association study (GWAS) and quantitative trait locus (QTL) mapping analyses even though research at present still lacks a meaningful scale to isolate key DNA regions (Figure 1). We propose that building up high-quality reference genomes in several representative species is pivotal for molecular dissection of domestication and for promoting the breeding of new varieties. Furthermore, the system biology approach integrated diverse analyses of high-throughput omics datasets, which will accelerate the discovery of key regulatory genes. 
Table 1. A list of recent transcriptomics studies in Camellia species related to trait variations and domestication.

\begin{tabular}{|c|c|c|c|c|c|}
\hline Species & Traits & Methods & Key Pathways \& Genes & Reference & $\begin{array}{l}\text { Database Accessment } \\
\text { (from NCBI) }\end{array}$ \\
\hline C. sinensis & seven tissue types & Transcriptome/Illumina & $\begin{array}{l}\text { flavonoid, theanine, and caffeine } \\
\text { biosynthesis pathways }\end{array}$ & [15] & $\begin{array}{c}\text { SRX020193, } \\
\text { HP701085-HP777243 }\end{array}$ \\
\hline \multicolumn{6}{|c|}{ Responses of Biotic and Abiotic Stress in Camellia Plants } \\
\hline C. sinensis & Cold acclimation & 454 GS-FLX & Cold-related genes & [16] & SRA061043, SRX020193 \\
\hline C. sinensis & Same as above & Illumina & AP2/ERF family TFs & [17] & Not found \\
\hline C. sinensis & $\begin{array}{l}\text { Leaves with different treatment } \\
\text { time of } 4 \text { or } 38^{\circ} \mathrm{C} \\
\text { temperature stress }\end{array}$ & Illumina & WRKY gen family & [18] & Not found \\
\hline C. japonica & $\begin{array}{l}\text { mature leaves after } 40 \mathrm{~d} \text { natural } \\
\text { low temperature }\end{array}$ & Illumina & $\begin{array}{l}\alpha \text {-linolenic acid and jasmonic acid } \\
\text { biosynthesis pathways respond to } \\
\text { cold acclimation }\end{array}$ & [19] & SRP076436 \\
\hline C. sinensis & $\begin{array}{c}\text { Drought stress and salt stress } \\
\text { young leaves }\end{array}$ & Illumina & Response to drought stress and salt stress & [20] & PRJEB11522 \\
\hline C. sinensis & $\begin{array}{c}\text { Germination seed of different } \\
\text { dehydrate treatment }\end{array}$ & Illumina & Mechanism of seed dehydration sensitivity & [21] & SRP096975 \\
\hline C. sinensis & $\begin{array}{c}\text { (NH4)2SO4 treatment buds, } \\
\text { leaves and root }\end{array}$ & Illumina & Nitrogen utilization genes & [22] & SRP077092 \\
\hline C. sinensis & $\begin{array}{c}\text { Pollen tubes at } 25^{\circ} \mathrm{C} \text { and } 4{ }^{\circ} \mathrm{C} \text { or } \\
\text { with NO treatment }\end{array}$ & Illumina & $\begin{array}{c}\text { Potential mechanisms of the participation of } \\
\text { NO in pollen tube responses to } \\
\text { low temperature }\end{array}$ & [23] & $\begin{array}{c}\text { SRR3270364, SRR3270376, } \\
\text { SRR3270829, SRR3270928, } \\
\text { SRR3270974, SRR3270993, } \\
\text { SRR3270997, SRR3271001, } \\
\text { SRR3271002 }\end{array}$ \\
\hline C. sinensis & $\begin{array}{l}\text { Leaf tissues of blister } \\
\text { blight transition }\end{array}$ & Illumina & Blister Blight defense & [24] & SRP067826, PRJNA306068 \\
\hline C. sinensis & Insect feeding treatment & Illumina & Defense response to insect (Ectropis. oblique) & [25] & SRX998353, SRX1543038 \\
\hline \multicolumn{6}{|c|}{ Transcriptomic Analyses in the Control of Secondary Metabolism in Camellia } \\
\hline C. sinensis & $\begin{array}{l}13 \text { different tissue samples from } \\
\text { various organs and } \\
\text { developmental stage }\end{array}$ & Illumina & Secondary metabolite biosynthesis pathways & [26] & $\begin{array}{l}\text { SRR1053623, SRR1051214, } \\
\text { SRR1054007, SRR1055110, } \\
\text { SRR1055182, SRR1054086, } \\
\text { SRR1054152, SRR1055108, } \\
\text { SRR1055109, SRR1055932, } \\
\text { SRR1055933, SRR1055934, } \\
\text { SRR1055944 }\end{array}$ \\
\hline
\end{tabular}


Table 1. Cont.

\begin{tabular}{|c|c|c|c|c|c|}
\hline Species & Traits & Methods & Key Pathways \& Genes & Reference & $\begin{array}{l}\text { Database Accessment } \\
\text { (from NCBI) }\end{array}$ \\
\hline C. taliensis & $\begin{array}{l}\text { Tender shoots, young leaves, } \\
\text { flower buds, and flowers }\end{array}$ & Illumina & Secondary metabolic biosynthesis pathways & [27] & PRJNA274899 \\
\hline C. sinensis & $\begin{array}{c}\text { Buds, 2nd leaves, mature leaves } \\
\text { and young roots }\end{array}$ & Illumina & Catechins metabolic pathways & [28] & Not found \\
\hline C. sinensis & $\begin{array}{l}\text { Leaf tissues of four tea } \\
\text { plant cultivars }\end{array}$ & Illumina & Catechins biosynthesis pathways & [29] & Not found \\
\hline C. asssamica & $\begin{array}{l}\text { Leaf at the purple and } \\
\text { green stages }\end{array}$ & Illumina & Anthocyanin biosynthesis pathway & {$[30]$} & Not found \\
\hline C. nitidissima & $\begin{array}{l}\text { Floral buds at five different } \\
\text { developmental stages }\end{array}$ & Illumina & $\begin{array}{c}\text { Carotenoids and flavonols glucosides } \\
\text { biosynthesis pathways }\end{array}$ & {$[31]$} & SRP112181 \\
\hline $\begin{array}{l}\text { C.nitidissima, } \\
\text { C. chuongtsoensis }\end{array}$ & S Young shoot tip or leaves & Illumina & Floral pigmentation and flowering timing & {$[32]$} & $\begin{array}{l}\text { PRJNA389977, } \\
\text { PRJNA400646 }\end{array}$ \\
\hline \multicolumn{6}{|c|}{ Transcriptomics Studies Related to Floral Patterning, Flowering Timing and Bud Dormancy } \\
\hline C. japonica & Double flower development & Illumina & $\begin{array}{l}\text { ABCE genes, miR156, and targeted } \\
\text { squamosa promoter binding } \\
\text { protein-likes (SPLs) }\end{array}$ & [33] & \\
\hline C. azalea & Floral buds & Illumina & Conserved and lineage-specific miRNA & [34] & PRJNA257896, SRP045386 \\
\hline C. sinensis & Axillary buds & Illumina & Bud dormancy regulation mechanism & [35] & SRR5040773, SRR5040784 \\
\hline C. sinensis & $\begin{array}{l}\text { Bud tissues of different } \\
\text { developmental stages }\end{array}$ & ABI PRISM 3730 & Dormancy-related genes & {$[36]$} & $\begin{array}{l}\text { HM003230-HM003378, } \\
\text { GW690681-GW691037 }\end{array}$ \\
\hline C. azalea & $\begin{array}{l}\text { Three stages of floral } \\
\text { bud development: }\end{array}$ & Illumina & $\begin{array}{l}\text { Floral dormancy-associated } \\
\text { MADS-box genes }\end{array}$ & [37] & PRJNA257896, SRP045386 \\
\hline C. sinensis & Three opening stages of flowers & Illumina & $\begin{array}{l}\text { WRKY, ERF, bHLH, MYB and MADS-box } \\
\text { family relate to flower development }\end{array}$ & [38] & $\begin{array}{l}\text { SRR5487532, SRR5487531, } \\
\text { SRR5487530, SRR5487529, } \\
\text { SRR5487528, SRR5487527, }\end{array}$ \\
\hline C. sinensis & $\begin{array}{l}\text { Two and a buds in July } \\
\text { and December }\end{array}$ & Illumina & $\begin{array}{l}\text { Regulatory mechanism of non-deciduous } \\
\text { habit in winter }\end{array}$ & [39] & Not found \\
\hline C. sinensis & $\begin{array}{l}\text { Shading leaves } \\
\text { (yellow leaf phenotype) }\end{array}$ & Illumina & $\begin{array}{l}\text { Chloroplast development, chlorophyll } \\
\text { biosynthesis pathway }\end{array}$ & {$[40]$} & SRX1078570 \\
\hline C. sinensis & $\begin{array}{l}\text { Adventitious roots from IBA } \\
\text { treatment cuttings }\end{array}$ & Illumina & $\begin{array}{l}\text { Potential mechanisms involved in } \\
\text { adventitious root formation }\end{array}$ & {$[41,42]$} & $\begin{array}{l}\text { PRJNA240661, } \\
\text { JK990996-991074 }\end{array}$ \\
\hline
\end{tabular}


Table 1. Cont.

\begin{tabular}{|c|c|c|c|c|c|}
\hline Species & Traits & Methods & Key Pathways \& Genes & Reference & $\begin{array}{l}\text { Database Accessment } \\
\text { (from NCBI) }\end{array}$ \\
\hline \multicolumn{6}{|c|}{ Transcriptomics in oil Camellia Plants } \\
\hline C. oleifera & Four tissues & 454 GS-FLX & Lipid metabolism & [43] & $\begin{array}{l}\text { SRR1472854, SRR1472847, } \\
\text { SRR1472843, SRR1472842, } \\
\text { GBHI00000000 }\end{array}$ \\
\hline C. oleifera & Drought treatment leaves & Illumina & Drought stress genes & [44] & SRP094080 \\
\hline C. oleifera & Seed & Illumina & Oil content and fatty acid composition & {$[45]$} & SRP111395 \\
\hline C. oleifera & $\begin{array}{l}\text { Leaves at different elevations } \\
\text { of Lu Mountain and } \\
\text { Jinggang Mountain }\end{array}$ & Illumina & Cold acclimation genes & [46] & $\begin{array}{l}\text { SRR2146977, SRR2146978, } \\
\text { SRR2146979, SRR2146980, } \\
\text { SRR2146973, SRR2146974, } \\
\text { SRR2146975, SRR2146976 }\end{array}$ \\
\hline C. chekiangoleosai & Seeds, flowers and leaves & 454 GS FLX & $\begin{array}{c}\text { Anthocyanin biosynthesis } \\
\text { pathway genes }\end{array}$ & [47] & Not found \\
\hline $\begin{array}{l}\text { C. oleifera, } \\
\text { C. meiocarpa }\end{array}$ & $\begin{array}{l}\text { Mature seed of different } \\
\text { moisture content }\end{array}$ & Illumina & $\begin{array}{l}\text { Fatty acid biosynthesis and } \\
\text { accumulation pathway }\end{array}$ & [48] & Not found \\
\hline $\begin{array}{l}\text { C. oleifera, } \\
\text { C. chekiangoleosa, } \\
\text { C. brevistyla }\end{array}$ & Flower buds & 454 GS FLX & $\begin{array}{l}\text { Secondary metabolites pathway, } C H S \\
\text { gene, } F A D 2 \text { gene }\end{array}$ & [49] & HQ704701.1 \\
\hline \multicolumn{6}{|c|}{ Markers Development Based on RNA-sequencing (RNA-seq) } \\
\hline C. sinensis & $\begin{array}{l}\text { Three developmental growth } \\
\text { stages leaves }\end{array}$ & 454 GS FLX & $\begin{array}{l}\text { Plant growth, development, secondary } \\
\text { metabolite, and (expressed sequence } \\
\text { tag-simple sequence repeats } \\
\text { (EST-SSR) markers }\end{array}$ & {$[50]$} & $\begin{array}{c}\text { SRA052793, } \\
\text { KA279444-KA304315, } \\
\text { HP701085-HP777243 }\end{array}$ \\
\hline C. sinensis & $\begin{array}{l}\text { Different flower organizations } \\
\text { at the big bud stage }\end{array}$ & Illumina & SSR Markers, SSR-based linkage map & [51] & $\begin{array}{c}\text { SRA053025, } \\
\text { GAAC01000001-GAAC0105291 }\end{array}$ \\
\hline $\begin{array}{l}\text { C. flavida, } \\
\text { C. achrysantha }\end{array}$ & Flower buds & Illumina & SSR markers & {$[52]$} & Not found \\
\hline C. oleifera & Lipid synthesis phase seed & Illumina & SSR markers & [53] & Not found \\
\hline
\end{tabular}




\section{Genetics and Genomic Resources in Genus Camellia Empowered by High-Throughput Sequencing}

Genus Camellia displays an extraordinary natural diversity in morphology, metabolites, habitats, etc. The artificial breeding of Camellia species results in excellent cultivars for producing beverages, ornamental flowers, and edible oil (Figure 1). These are the main purposes of breeding and cultivation of Camellia varieties and the related research is also carried out around these breeding targets. Camellia sinensis var. assamica was the first species in Camellia with a high-quality genome reference in which 3.02-Gb base pairs DNA sequences were assembled [14]. In 2018, the genomic sequence of $C$. sinensis var. sinensis was reported [13]. Through the study of two C. sinensis genomes, the researchers found that whole-genome duplication events and subsequent paralogous duplications had major impacts on the gene family members related to the biosynthesis of secondary metabolites such as catechins, theanine, and caffeine $[13,14]$. The high-quality genomes in Camellia will greatly facilitate fundamental research relevant to trait variations through the analyses of comparative and functional genomics.

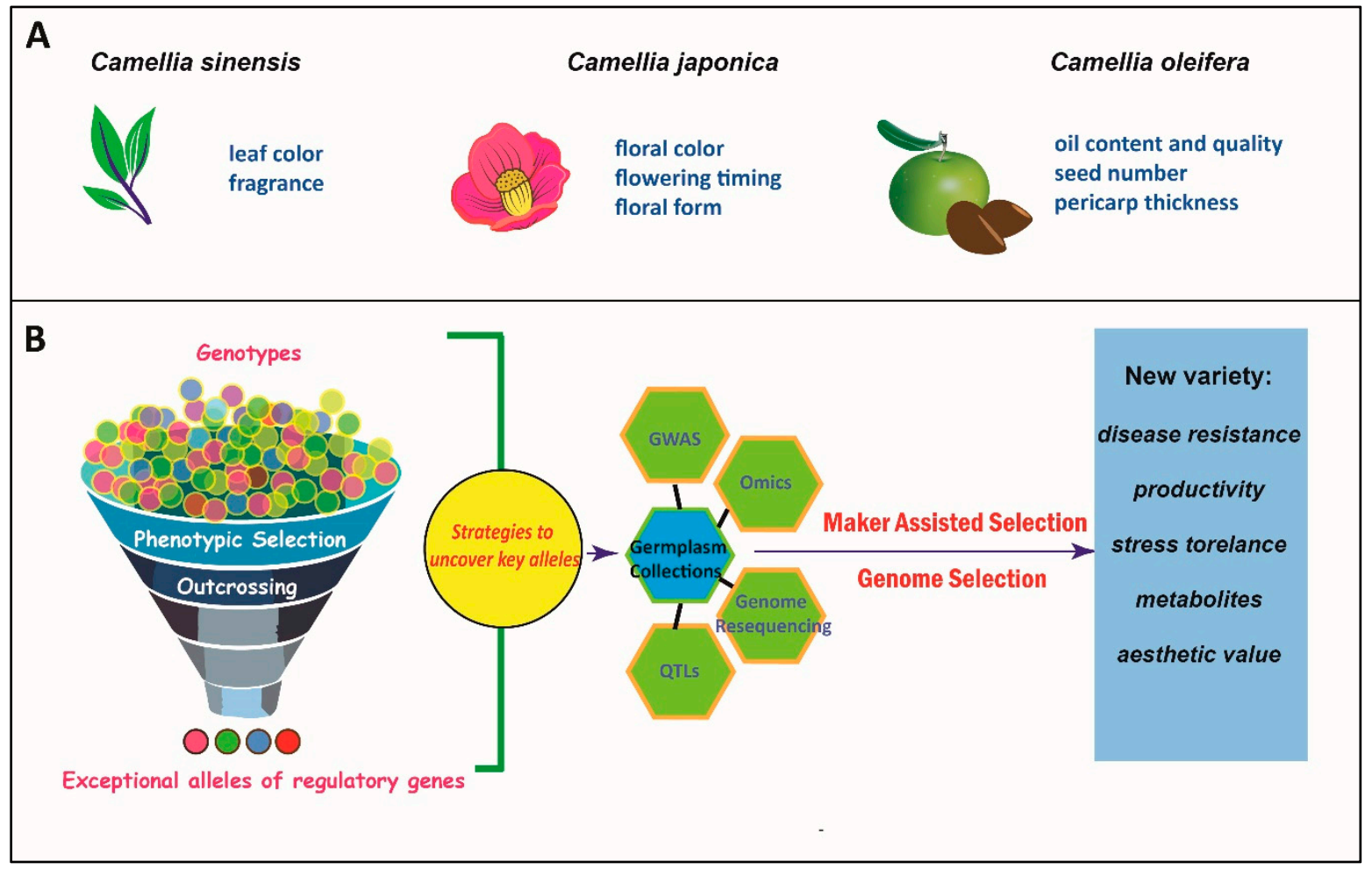

Figure 1. An illustrated cartoon summarizing the domestication in Camellia species. (A) The leaves, flowers, and fruits (seeds) of Camellia plants are useful organs to produce economic products for human living. Major domestication targets of each organ and representative species are listed. (B) The domestication process yields some valuable alleles contributing to trait variations in cultivars. To identify underlying genes or associated molecular makers, strategies based on germplasm collection (natural or forced hybridization populations) are subjected to various types of analyses such as genome-wide association study (GWAS), multiple omics tools, genome re-sequencing, and quantitative trait locus (QTL) mapping. The uncovered markers and genes associated with key traits are pivotal for understanding the mechanism of domestication and improving new varieties in Camellia. With the support of maker assisted selection and genome selection approaches, the domestication program of Camellia plants can be more efficiently and precise for breeding cultivars of economic values.

Transcriptomics studies in various Camellia plants were performed extensively in both wild and cultivated plants. The first comprehensive transcriptome analysis in C. sinensis by the second generation sequencing was reported in 2011 using an Illumina GA II sequencing platform [15]. This work sequenced 
a mixed sample containing seven tissue types and yielded 127,094 uni-genes, which provided a dataset for gene discovery not only for tea plants but also other Camellia species [15]. Along with the rapid development of sequencing technology, the RNA-seq studies of Camellia were applied dramatically to enhance our understanding of how genes are expressed under various conditions. In this case, we focus on transcriptomics studies in Camellia plants under a variety of experimental designs (Table 1).

\subsection{Responses of Biotic and Abiotic Stress in Camellia Plants}

Various RNA-seq analyses targeting biotic and abiotic stresses in C. sinensis were performed to identify responsive genes. In those RNA-seq analyses, the majority of them characterize abiotic stress responsive genes including temperature, drought, salinity, nitrogen, etc. Genes responsive to a low temperature were identified in C. sinensis by several RNA-seq analyses, which revealed some potential signaling pathways underlying cold acclimation [16]. Among the 1770 differentially expressed transcripts, potential cold sensors, detoxification enzyme genes, and transcription factors were identified [16]. Based on the previously mentioned transcription database, the 89 APETALA2/ethylene responsive factor (AP2/ERF) and 50 putative WRKY proteins, which might be related to abnormal temperature stress, were identified $[17,18]$. In Camellia japonica, the cold responses were compared between cold sensitive and cold hardy genotypes through a transcriptomics analysis and $\alpha$-linolenic acid and jasmonic acid biosynthesis pathways were proposed as key factors related to low temperature acclimation [19]. Salinity and drought tolerance is another focus of plant breeding and cultivation and has an important influence on plant growth [54]. To understand the gene expression profiles, the RNA-seq experiments under drought and salt stress treatments of $C$. sinensis were conducted, and 3936 and 3715 differentially expressed genes (DEGs) were identified upon drought and salt stress, respectively [20]. Further comparative analyses of DEGs indicated that these two stresses had some common molecular effects, which indicates that shared pathways were involved [20]. The seed germination process of Camellia was also found to be sensitive to drought stress. Through transcriptomics analysis under the dehydration treatments, 91,925 non-redundant uni-genes were obtained. A series of genes that have been reported to function in the dehydration process were found to be downregulated including ABA biosynthesis and signal transduction, transcription factor, antioxidant enzyme, etc. [21].

Nitrogen $(\mathrm{N})$ is one of three essential factors in higher plants, which is critical for plant growth. The transcriptomes of buds, leaves, and the root of $C$. sinensis with or without $\left(\mathrm{NH}_{4}\right)_{2} \mathrm{SO}_{4}$ treatments were studied and 196 and 29 common DEGs in roots and leaves were identified, respectively [22]. Through quantitative reverse transcription PCR (RT-qPCR) analysis, some N uptake and assimilation genes were validated [22]. Nitric oxide (NO) was found to be an important signaling factor regulating plant growth under a stress condition [55] especially in low temperature stress [56,57]. In order to reveal potential mechanisms of $\mathrm{NO}$ responses to a low temperature, transcriptomes of pollen tubes at $25{ }^{\circ} \mathrm{C}(\mathrm{CK})$ and $4{ }^{\circ} \mathrm{C}(\mathrm{LT})$ or with NO treatment (NO) were studied [23] and 766,497 and 929 DEGs were found among CK-VS-LT, CK-VS-NO, and LT-VS-NO comparisons [23]. These results provided molecular evidence of linking $\mathrm{N}$ assimilation and cold stress in Camellia plants.

Most of Camellia species originate from Southeastern Asia, which has a warm and humid climate that is particularly suitable for pest and disease propagation. In such an environment, Camellia plants generally have strong biotic resistance. The disease resistance ability is an important index in the Camellia plant Breeding. Artificial cultivation of a single species weakened Camellia plant biotic resistance. Some diseases and insect pests seriously affect the economic value of Camellia plants such as tea blister blight (BB), anthracnose, Ectropis oblique, etc. The tea BB has a great influence on the quality of tea [58]. The molecular mechanism of the C. sinensis defense against the BB disease was studied [24]. The transcriptomes of BB transition leave tissues were analyzed along with 149 DEGs including defense related enzymes, resistance genes, multidrug resistant transporters, etc. It was suggested that they have a role in defending against BB [24]. Anthracnose is one of the most important diseases restricting the development of Oil Camellia species [59]. The correlations of Camellia oleifera disease resistance 
and the enzyme (peroxidase, catalase, superoxide dismutase, and polyphenol oxidase) activity were analyzed. It is found that infection of pathogenic bacteria caused the significant changes of the activity of defensive enzymes in different Camellia varieties [60]. To elucidate the molecular mechanisms of the response to E. oblique in tea plants, the transcriptomes of E. oblique damage-induced leave tissues were analyzed and 1859 DEGs were identified [25]. Upon further analysis, this DEGs found that genes involved in secondary metabolites and signaling pathways were differentially regulated after feeding by E. oblique [25].

\subsection{Transcriptomic Analyses in the Control of Secondary Metabolism in Camellia}

Transcriptomics studies were applied to understand various developmental processes of Camellia plants. Particularly in tea plants, global gene expression profiling along with the development of leaf, flower, and seed germination were effective in identifying potential regulatory genes (Table 1). Camellia is rich in many secondary metabolites including flavonoids, catechins, theanine, anthocyanins, etc. Many of these secondary metabolites are not only essential to the flavors of tea drinks but also have a significant impact on horticultural value of Camellia. There were many RNA-seq studies related to secondary metabolites of Camellia. For example, the transcriptomes of 13 different samples from various organs and developmental stages of $C$. sinensis were studied and 347,827 uni-genes were assembled and annotated in which 1719 uni-genes were identified as being involved in the secondary metabolic pathways [26]. In Camellia taliensis, the transcriptomes of tender shoots, young leaves, flower buds, and flowers were studied and candidate genes for major metabolic pathways were found [27]. The biosynthetic pathway of catechins were also studied [28,29]. Through the transcriptomics analysis of leaf tissues from four tea plant cultivars (C. sinensis), 146,342 pairs of putative orthologs were generated and 217 common DEGs were found [29]. A similar work characterized the four tissue types of $C$. sinensis in which 36 catechins and flavonoids biosynthesis were identified [28]. These studies indicated that the biosynthesis pathways of secondary metabolites in different Camellia species were largely conserved and the changes of regulatory genes might play a key role in the diversity of chemical compositions.

The diverse pigments of Camellia plants are attractive to breeders. Some ornamental traits such as purple leaves, golden flowers, and double flowers were characterized through different transcriptomics approaches. To understand the alterations of the leaf color of $C$. sinensis var. assamica, a transcriptomics comparison between green and purple leaves was performed, which yielded 2250 DEGs that were potentially related to the biosynthesis of anthocyanins [30]. In yellow Camellia (Camellia nitidissima) species, the transcriptomes of floral buds at five different developmental stages were investigated and, through characterization of DEGs, the accumulation of carotenoids and flavonols glucosides in the petals was revealed as potential underlying floral pigments [31]. A recent work investigated two transcriptomic datasets in C. nitidissima and Camellia chuongtsoensis [32]. Comparative analyses of gene expression profiles in yellow and red flowered Camellia species revealed that the direct glucosidation of flavonols was a key regulatory step of accumulating yellow pigments [32].

\subsection{Transcriptomics Studies Related to Floral Patterning, Flowering Timing, and Bud Dormancy}

The double flower formation in Camellia is a major aesthetic trait for ornamental Camellia plants. An integrative analysis using small RNA, transcriptome, and degradome sequencing technologies in wild and domesticated double flower cultivars was performed [33]. Through gene expression and functional enrichment analyses, the formation of double flowers was found to be controlled by a coordination of micro RNAs (miRNAs) and some floral regulators [33]. There were only a few works reported in Camellia characterizing the miRNA genes. Through small RNA-seq of different floral organs in C. azalea, 175 miRNAs were identified and 12 Camellia specific miRNAs were revealed [34]. The differentially expressed miRNAs and their targets were analyzed and some miRNA-target regulations were identified as important factors in the control of floral organ development in Camellia [34]. 
Bud dormancy is an important evolutionary adaptation to local climatic conditions, which enables the survival in winter or dry seasons. In C. sinensis, cold winter dormancy also affected the economic output of the tea plant [35]. The transcriptomes of bud tissues (C. sinensis) of different developmental stages were studied. The putative role of identified genes in growth and dormancy of tea were discussed [36]. Transcriptomes of axillary buds (C. sinensis) of different dormancy types and bud flush stages were identified and 16,125 DEGs were identified in different measured conditions, which suggested that the dormancy regulation of the tea plant were consistent with that of Poplar [35]. In Camellia azalea, which is a newly discovered species with unique and prolonged blooming periods, the transcriptomes of floral buds at different developmental stages were investigated and the dormancy associated MADS-box genes were further analyzed, which showed that Short Vegetative Phase (SVP-) and Agamous-like24 (AGL24-) genes played critical roles during floral bud development [37]. In Camellia sinensis, a transcriptomic analysis of flower development revealed several types of transcription factors including WRKY, the Ethylene Responsive Factor (ERF), the basic Helix-Loop-Helix (bHLH), the Myeloblastosis (MYB), and the MADS-box family, which were related to floral transition [38].

Some other transcriptomic studies were conducted to understand environmental or hormonal regulations in Camellia plants. In order to understand the non-deciduous habit of C. sinensis, transcriptomes of buds in July and December were analyzed and 24,700 uni-genes were obtained, which were related to the operation of winter tolerance [39]. In a transcriptomics study of shading treatment of "Baijiguan" (C. sinensis) leaves, 1993 and 2576 DEGs were identified in plants treated with three and six days of shading, respectively [40]. It is postulated that the high light intensity might affect PSII stability, chloroplast development, and chlorophyll biosynthesis by inhibiting the expression of the photosystem II10- $k$ Da protein (Psb R) [40]. The transcriptomes of adventitious roots (C. sinensis) with and without Indole-3-Butyric Acid treatment were compared [41,42] and 656 up-regulated and 435 down-regulated genes were identified. Functional annotation analysis revealed the potential mechanism relevant to the control of the adventitious rooting process [42].

\subsection{Transcriptomics in Oil Camellia Plants}

Almost all of Camellia seeds have some certain oil contents. Oil Camellia referred to a kind of Camellia species that the main cultivated purpose was seeds oil content including C. oleifera, Camellia meiocarpa, Camellia chekiangoleosa, etc. C. oleifera was the most important species in oil Camellia. In C. oleifera, about 60 million RNA-Sequence reads from four tissues were generated and assembled into 104,842 non-redundant putative transcripts [43]. This work greatly increased the transcripts sequences for gene discovery and identified 3022 pairs of orthologs compared with C. sinensis [43]. The transcriptomes of $C$. oleifera leaves under drought treatments were studied. A series of DEGs associated with drought stress responsive pathways were identified among which 789 DEGs were transcription factors [44]. In a recent study, transcriptomes of C. oleifera seeds at different oil accumulation stages were characterized and valuable DEGs that were associated with the seed oil accumulation were uncovered [45]. By studying the transcriptomes of $C$. oleifera leaves at different elevations of Lu Mountain and Jinggang Mountain in China, abundant simple sequence repeats (SSRs), Single nucleotide polymorphisms (SNPs), and insertion/deletions were identified and many DEGs at different environmental temperatures were discovered [46].

Different varieties of oil Camellia had their own characteristics. In order to reveal the mechanism of phenotypic differences, the transcriptomes of various oil Camellia cultivars were analyzed. C. chekiangoleosa was a kind of oil Camellia with red flowers. In C. chekiangoleosa, RNA-Seq datasets and Expressed Sequence Tag (EST) library were generated to study genes involved in anthocyanin and seed oil biosynthesis [47]. The transcriptomes of C. meiocarpa and C. oleifera seeds, which have different moisture contents, were analyzed. In addition, 244 genes involved in fatty acid synthesis and accumulation were identified and gene ontology enrichment indicated that fatty acid accumulation is essential in C. meiocarpa and C. oleifera during the natural drying process [48]. A comparative study 
using C. oleifera, C. chekiangoleosa, and Camellia brevistyla was performed. The expression levels of Chalcone Synthase (CHS) and Fatty Acid Desaturase 2 (FAD2) were compared in different cultivars [49].

\subsection{Markers Development Based on RNA-Sequencing}

RNA-sequence data were widely used in the development of the molecular markers of Camellia. To facilitate the molecular breeding in Camellia plants, the database of transcriptome of C. sinensis was used for the development of SSR molecular markers. Wu et al. (2012) identified 3767 EST-SSRs potential molecular from C. sinensis leaf transcriptome [50]. The transcriptomes of different floral organs (petals, pistils, and stamens) of $C$. sinensis were analyzed and 75,531 uni-genes were assembled and generated 431 novel polymorphic SSR markers [51]. In Camellia flavida, 38 polymorphic microsatellite loci were identified based on the transcriptome sequencing and polymorphic alleles between C. flavida and C. nitidissima were revealed [52]. In C. oleifera, molecular markers were also developed and 6949 putative SSR motifs were discovered from a seed transcriptome from which 15 polymorphic genic-SSR markers were verified [53].

\section{GWAS and QTL Mapping of Key Traits in Camellia Plants}

Quantitative trait locus mapping is a powerful method for identifying the key genome regions related to the traits of interest [61]. Previously, QTL analyses were performed in many major crops through the marker-assisted breeding methods [62-66]. Genetic linkage maps constructed with various molecular markers are particularly useful for mapping of QTLs. To date, over 10 genetic maps were constructed in tea plants based on different types of markers such as Random Amplification of Polymorphic DNA (RAPD), the Inter-Simple Sequence Repeat (ISSR), Amplified Fragment Length Polymorphism (AFLP), SSR, SNP, and more [51,67-77]. In addition, QTLs for tea plant yield [73], timing of spring bud flush, young shoot color [77], catechins content [75], drought tolerance [67], etc., were mapped. However, these previously mentioned genetic maps were constructed with a low resolution due to the limits in genotyping methods and the size of segregating populations. The research of QTL mapping in tea plants is at a preliminary stage and needs more in-depth developments of molecular markers and linkage maps.

To our knowledge, the genetic map construction and QTL mapping in other Camellia species are not reported. There are two potential reasons limiting the study in Camellia plants. First, it requires a large population to achieve sufficient segregations of allelic variations [78], which causes vast efforts for data collecting. Second, the commonly appearing polyploidization of Camellia cultivars increases the difficulty of fine QTL mapping. In recent years, the high-throughput sequencing technology allows genome-wide genetic variation discovery and genotyping in a highly efficient way [79]. It can greatly increase the resolution of QTL mapping and reduce laborious works [80,81]. Genome-wide association study based on high-throughput sequencing technologies is considered a favorable resolution to explore the allelic variation in a broader scope for extensive phenotypic diversity and as a complementary and powerful tool for connecting the genotype-phenotype map as well. GWAS overcomes the cross-population limitation of QTL mapping and evaluates the association between genotypes and phenotypes of interest based on the natural population with a large number of unrelated individuals. This approach was pioneered in human genetics more than 10 years ago [82] and were now routinely applied in plants including Arabidopsis [83] and crops [84-91]. In tree plants, the genome re-sequencing of 544 Populus trichocarpa trees and GWAS analysis identified extensive genomic regions related to adaptive trait variation [92]. Due to the abundant genetic diversity and rapid Linkage Disequilibrium (LD) decay, the out-crossing species are suitable for GWAS such as Camellia species. However, up to now, GWAS analysis in Camellia plants was not reported yet. Due to the complexity of the Camellia genome, the genome-wide analysis of Camellia population genetics is unfinished and the extensive heterozygosity in the Camellia genome makes the polymorphism calling technically challenging. The further efforts of GWAS in cultivated Camellia plants are needed. There are some precautions in cultivated Camellia GWAS work when the reference genome 
is available. First, the population size and sequencing coverage are fundamental in an experimental design. Large samples and high coverage will increase GWAS power generally and also enable most allelic variants to be identified. However, it is not always more or better in sampling (especially in plant samples) because the diversity and the individual relationship can greatly affect the effect of GWAS [79]. To achieve cost optimizations, a balance between sequencing depth and sample size should be made. Phenotyping is the most laborious and important work in Camellia GWAS. A well-defined trait will increase GWAS power. To ensure the quality of phenotype data, it would be much better to generate phenotype data in several successive years with replications and careful field designs. When a trait is strongly confounded by genetic backgrounds, the power of GWAS will be greatly reduced [79]. An appropriate statistical model can reduce spurious genotype-phenotype associations and increase GWAS power. Computational models including mixed linear, multi-locus mixed, and multi-trait mixed models, which integrate the population structure matrix and pairwise relatedness kinship within populations, have been developed, improved, and optimized to control the rate of spurious genotype-phenotype associations [93-97]. Lastly, in the light of a high-quality reference genome of Camellia species, the integration of GWAS and QTL would provide more accurate information of regulatory genes underlying the complex traits. It is expected that, with the support of population, association, and designated omics datasets, the casual loci could be identified.

\section{Functional Characterization of Genes Related to Key Pathways of Camellia Plants}

The enormous amount of transcriptomics studies in Camellia plants facilitated the in-depth analysis of genes or gene families related to some fundamental pathways such as floral and fruit development, secondary metabolites, or stress tolerances. For instance, the members of Uridine 5'-diphospho (UDP)-glycosyltransferases in tea (132 transcripts in total) were systematically identified based on transcriptome sequencing [98] and functional analyses revealed that three UDP-glucuronosyltransferases (UGTs) were involved in the biosynthesis of $\beta$-glucogallin and glycosylated flavonols [98]. Furthermore, a comparative transcriptomics work that focused on two yellow Camellia species (C. nitidissima and C. chuongtsoensis) suggested that the group C clade of the UGT family was expanded in yellow Camellia plants, which was consistent with higher flavonoids levels [32]. These results have highlighted the importance of various genomic datasets in genus Camellia to understand the evolutionary adaptations of natural traits.

Yet, current research in Camellia plants is hampered by a lack of sufficient molecular tools to validate the functions of underlying genes. Detailed characterization of gene functions in Camellia plants remains scarce. To dissect the important economic traits of Camellia cultivars, versatile molecular biology toolkits are of significant importance. Currently, transgenic analysis of model plants (e.g., Arabidopsis, tobacco) and in vitro protein assays are most commonly used. In a recent study, the enzymatic activities of Lipoxygenases (LOX) from C. sinensis were evaluated and the efforts of gene expression and subcellular localization indicated CSLOX genes were related to diverse stress responses [99,100]. To study the formation of double flowers in C. japonica, homologs of classic ABC model genes were identified and characterized. Through the gene expression and transgenic Arabidopsis analyses, it was found that the expression levels of A class genes were positively correlated with the degree of floral doubleness [101] while the $C$ class homolog displayed distinct expression patterns in different types of double flowers in cultivated Camellia [102]. It is not clear how the ABC genes are domesticated at the molecular level during double flower formation. The integrative analyses of small RNAs and their targets in doubled Camellia cultivars suggested that miRNAs-target regulations played a critical role in the floral organ development of double flowers [33]. Hence, the development of double flowers in Camellia required multiple types of regulatory genes including $\mathrm{ABC}$ function genes, miRNAs, targets, and other factors.

The Camellia fruits were artificially selected mostly for the production of edible oil of seed kernels. It was found that Camellia oil is unique in a high level of unsaturated fatty acids and other metabolites 
beneficial for human health [45]. There was a great diversity of fruit structure of Camellia plants used for oil production (Figure 2).

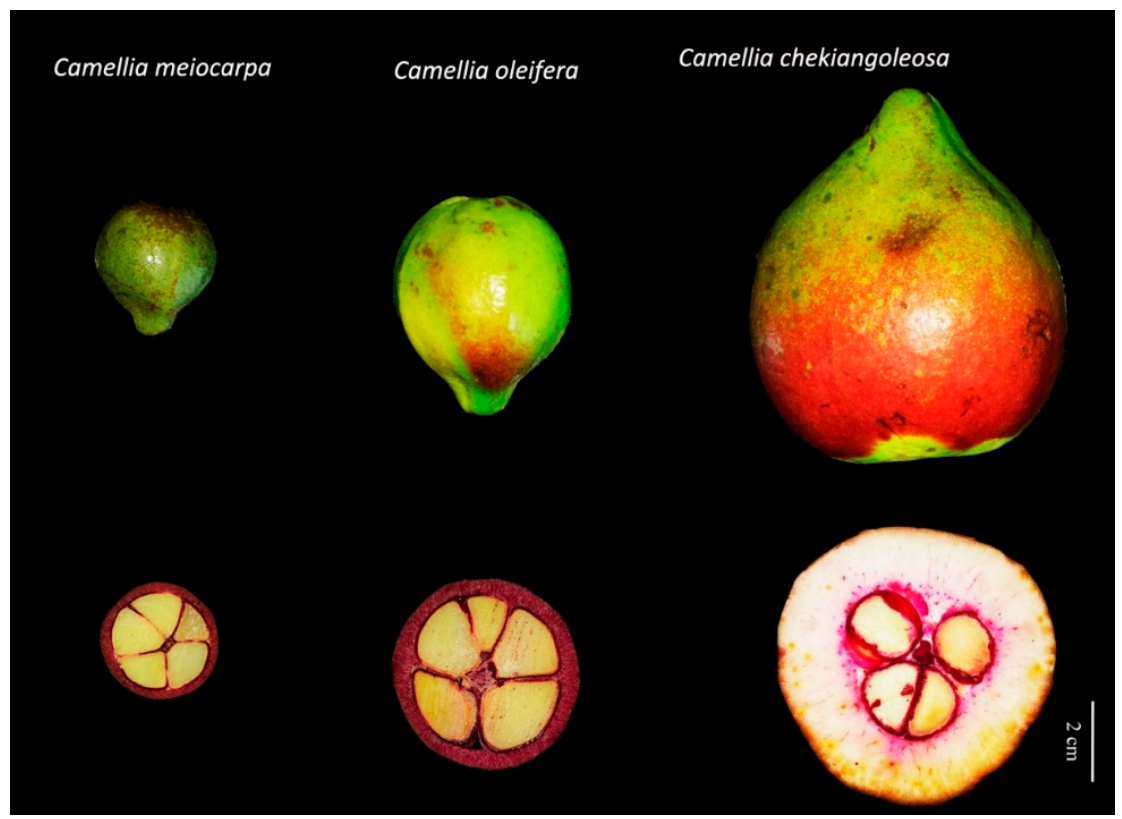

Figure 2. A comparison of oil-Camellia fruits and their lignification patterns. The fruits at the stage of rapid enlargement (from left to right, C. meiocarpa, C. oleifera, and C. chekiangoleosa) are presented on the upper panel. The lignification pattern of fruits is revealed by a red color of phloroglucinol-HCl staining on the lower panel.

Besides the plants domesticated from C. oleifera, other species with a distinct floral color and flowering time (e.g., C. chekiangoleosa, Camellia polyodonta, Camellia reticulata) were also commonly used for oil production. The comparison of fruit anatomy and a lignification pattern indicated that the genetic alterations of regulatory pathways were underlying the fruit development and ripening during the evolutionary and domestication processes (Figure 2). However, few genes related to Camellia fruit development were characterized at present. Taking advantage of the diversity of fruit shape, size, and metabolite in closely related species (Figure 2), which is the fruit development of Camellia, served as an ideal system to study the molecular regulation of seed oil biosynthesis, secondary metabolism, lignification, etc.

Genetic factors regulating fruit development were uncovered mostly based on studies in model plants such as the Arabidopsis silique development and tomato ripening processes [103-105] (Figure 3). Currently, several types of transcription factors were found to work coordinately to regulate hormone signaling, lignification, and secondary metabolite biosynthesis during fruit development [106-108]. In Arabidopsis, three MADS-BOX transcription factors (FUL, SHP1, and SHP2) formed a central regulatory node directing the patterning of fruit development [109]. The homolog of SHP1/2 in tomatoes was found to regulate a diverse process during fruit development and ripening [110]. The bHLH type transcription factors (Lc, Alcatraz) were also revealed as key regulators during fruit development in petunia and Arabidopsis [111-113]. Moreover, NAC (no apical meristem (NAM), activating factor1,2 (ATAF1,2), and cup-shaped cotyledon2 (CUC2)) and MYB transcription factors played important roles in the biosynthesis of the cell wall and secondary metabolites in fruits, which together formed a complex network governing the formation of different fruit morphologies [114-116]. 


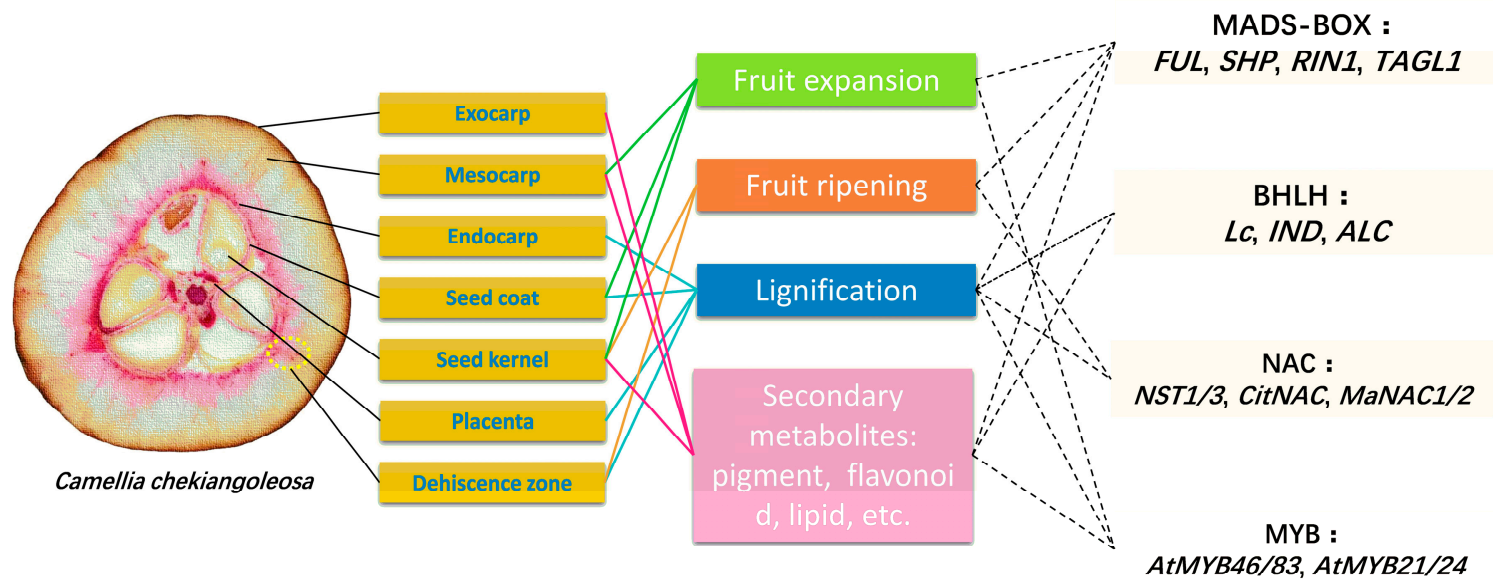

Figure 3. A proposed diagram of transcription factors in the control of fruit development in C. chekiangoleosa. A typical fruit of $C$. chekiangoleosa consists of a variety of tissue types that are labeled by yellow boxes. During the development of fruit, some processes including fruit expansion, fruit ripening, lignification, and biosynthesis of secondary metabolites are found to be controlled by several types of transcription factors, according to the studies from diverse plant species. The yellow ellipse indicates the dehiscence zone.

The genetic model was found to be useful for investigating the regulation of fruit development in other types of fruits [117-119]. The Camellia fruit development shares some common processes with other plants such as the lignification of endocarp and flavonoid biosynthesis, which suggests that these transcription factors may also be involved (Figure 3). We examined the structure of $C$. chekiangoleosa fruits and showed that the endocarp and seed coat were lignified at the fruit ripening stage, which were potentially regulated by MADS-BOX and NAC types of transcription factors (Figure 3). The pericarp of $C$. chekiangoleosa was enriched in flavonoids, which could be directed by MYB type transcription factors (Figure 3). It is not clear how the transcriptional regulation participates in the fruit development in Camellia plants. Future work of functional analyses of the transcription factors is needed to reveal the diversity of Camellia fruit development.

The regulatory genes related to biotic and abiotic stresses in Camellia were essential to cultivate new varieties with enhanced environmental resilience and field performance. Presently, regulatory genes, particularly transcription factors and their targets, were discovered extensively in Camellia species $[16-18,120]$. However, only a few genes of transcription factors were characterized through transgenic analysis in model species. For example, a basic region/leucine zipper (bZIP) transcription factor in C. sinensis (CsbZIP6) was studied. Enhanced tolerances of freezing stress were revealed in transgenic Arabidopsis plants [121]. Further studies indicated that CsbZIP6 might induce downstream cold-responsive genes in Arabidopsis [121]. A dehydration-responsive element-binding protein (DREB) transcription factor (CSDREB) was identified and characterized [122]. Overexpression of CsDREB in Arabidopsis revealed that CsDREB was involved in salt and drought tolerances via both ABA-dependent and ABA-independent pathways [122]. In Camellia plants, the lack of an efficient transformation system hampered the functional analysis of key regulators. However, transient expression or callus transformation approaches might be effective for addressing the regulatory functions of transcription factors related to stress tolerances.

\section{Future Perspectives: A Roadmap for Camellia}

As the demand for Camellia products continues to increase, the current breeding work is facing a challenge of obtaining cultivars with enhanced environmental resilience and productivity. To meet the challenges, the large-scale gene expression analysis is becoming a prevalent methodology in the field of Camellia research, which greatly facilitates the molecular characterization of important 
gene families. With the support from large natural or hybridized populations, it is expected that more and more genetic factors or loci will be available for improving the efficiency of breeding new varieties (Figure 1). However, a deep understanding of the molecular mechanism of trait evolution and domestication relies on the capability of functional tools. The facile genetic transformation or transient assay systems in Camellia plants are essential to test the hypothesis relevant to candidate gene functions. Lastly, the genome editing technology together with other molecular breeding technologies will enable a precise and targeted innovation of new traits and genetic variations.

We propose a practical roadmap for Camellia research including four key steps. (1) A large-scale collection of germplasms of native and hybrid populations is necessary to advance Camellia research. (2) Database initiatives and analyzing platforms for genomics, metabolites, and phenotypes. An international cooperation platform will facilitate the storage, sharing and analysis of high-throughput data, and provide opportunities for generating standardized pipelines for various Camellia breeding programs. (3) With the support of reference genomes in Camellia plants, the application of genomics tools through whole-genome level analyses (such as QTL mapping, GWAS, and genome re-sequencing) will allow an efficient identification of molecular markers or gene alleles associated with trait variations. (4) Take advantage of the molecular information. The maker assisted selection can help locate important genomic fragments underlying key economic traits. At the same time, the genome selection method is a promising approach to shorten the breeding cycle and integrate elite traits efficiently based on models from whole-genome analyses of molecular makers. Presently, a large number of wild Camellia resources are still underutilized and it is expected that, with the support of genomic technologies, the domestication of Camellia plants can promote the breeding of elite varieties with enhanced resistances and economic values in the near future.

Author Contributions: H.Y., X.Y., and J.L provided ideas and supervised the writing of manuscript. C.Y. and P.L. performed the reference analysis and drafted the manuscript. T.L., Z.H., X.L., and Z.F participated in writing and editing of the manuscript. All authors contributed to the writing of the paper.

Funding: This work was supported by Nonprofit Research Projects (CAFYBB2016SZ001) of Chinese Academy of Forestry and the National Science Foundation of China (NSFC) Grant 31470697. We also acknowledge the support from the Forestry Industry Research Special Funds for Public Welfare Projects (201504707) and International Sci. \& Tech. Cooperation Program of China (2016YFE0126100).

Acknowledgments: We thank Haobo Guo from the University of Tennessee Chattanooga for discussing some ideas of the manuscript. We are grateful to anonymous reviewers for valuable suggestions to improve the manuscript.

Conflicts of Interest: The authors declare no conflict of interest. The funders had no role in the design of the study, in the collection, analyses, or interpretation of data, in the writing of the manuscript, or in the decision to publish the results.

\section{References}

1. Lenser, T.; Theißen, G. Molecular mechanisms involved in convergent crop domestication. Trends Plant Sci. 2013, 18, 704-714. [CrossRef] [PubMed]

2. Abbo, S.; Pinhasi van-Oss, R.; Gopher, A.; Saranga, Y.; Ofner, I.; Peleg, Z. Plant domestication versus crop evolution: A conceptual framework for cereals and grain legumes. Trends Plant Sci. 2014, 19, 351-360. [CrossRef] [PubMed]

3. Lin, Z.; Li, X.; Shannon, L.M.; Yeh, C.T.; Wang, M.L.; Bai, G.; Peng, Z.; Li, J.; Trick, H.N.; Clemente, T.E.; et al. Parallel domestication of the Shattering1 genes in cereals. Nat. Genet. 2012, 44, 720-724. [CrossRef] [PubMed]

4. Fuller, D.Q.; Denham, T.; Arroyo-Kalin, M.; Lucas, L.; Stevens, C.J.; Qin, L.; Allaby, R.G.; Purugganan, M.D. Convergent evolution and parallelism in plant domestication revealed by an expanding archaeological record. Proc. Natl. Acad. Sci. USA 2014, 111, 6147-6152. [CrossRef] [PubMed]

5. Purugganan, M.D.; Fuller, D.Q. The nature of selection during plant domestication. Nature 2009, 457, 843-848. [CrossRef] [PubMed]

6. Xu, Q.; Chen, L.L.; Ruan, X.; Chen, D.; Zhu, A.; Chen, C.; Bertrand, D.; Jiao, W.B.; Hao, B.H.; Lyon, M.P.; et al. The draft genome of sweet orange (Citrus sinensis). Nat. Genet. 2013, 45, 59-66. [CrossRef] [PubMed] 
7. Wu, G.A.; Prochnik, S.; Jenkins, J.; Salse, J.; Hellsten, U.; Murat, F.; Perrier, X.; Ruiz, M.; Scalabrin, S.; Terol, J.; et al. Sequencing of diverse mandarin, pummelo and orange genomes reveals complex history of admixture during citrus domestication. Nat. Biotechnol. 2014, 32, 656-662. [CrossRef] [PubMed]

8. International Peach Genome Initiative; Verde, I.; Abbott, A.G.; Scalabrin, S.; Jung, S.; Shu, S.; Marroni, F.; Zhebentyayeva, T.; Dettori, M.T.; Grimwood, J.; et al. The high-quality draft genome of peach (Prunus persica) identifies unique patterns of genetic diversity, domestication and genome evolution. Nat. Genet. 2013, 45, 487-494. [CrossRef] [PubMed]

9. Zhang, Q.; Chen, W.; Sun, L.; Zhao, F.; Huang, B.; Yang, W.; Tao, Y.; Wang, J.; Yuan, Z.; Fan, G.; et al. The genome of Prunus mume. Nat. Commun. 2012, 3, 1318. [CrossRef] [PubMed]

10. Wu, G.A.; Terol, J.; Ibanez, V.; Lopez-Garcia, A.; Perez-Roman, E.; Borreda, C.; Domingo, C.; Tadeo, F.R.; Carbonell-Caballero, J.; Alonso, R.; et al. Genomics of the origin and evolution of citrus. Nature 2018, 554, 311-316. [CrossRef] [PubMed]

11. Gao, J. Collected Species of the Genus Camellia- an Illustrated Outline; Zhejiang Science and Technology Publishing House: Hangzhou, China, 2005; pp. 12-35. ISBN 978-7534125942.

12. Sealy, J.R. A revision of the Genus Camellia; Royal Horticultural Society: London, UK, 1958; pp. 1-235.

13. Wei, C.; Yang, H.; Wang, S.; Zhao, J.; Liu, C.; Gao, L.; Xia, E.; Lu, Y.; Tai, Y.; She, G.; et al. Draft genome sequence of Camellia sinensis var. Sinensis provides insights into the evolution of the tea genome and tea quality. Proc. Natl. Acad. Sci. USA 2018, 115, E4151-E4158.

14. Xia, E.H.; Zhang, H.B.; Sheng, J.; Li, K.; Zhang, Q.J.; Kim, C.; Zhang, Y.; Liu, Y.; Zhu, T.; Li, W.; et al. The tea tree genome provides insights into tea flavor and independent evolution of caffeine biosynthesis. Mol. Plant 2017, 10, 866-877. [CrossRef] [PubMed]

15. Shi, C.Y.; Yang, H.; Wei, C.L.; Yu, O.; Zhang, Z.Z.; Jiang, C.J.; Sun, J.; Li, Y.Y.; Chen, Q.; Xia, T.; et al. Deep sequencing of the Camellia sinensis transcriptome revealed candidate genes for major metabolic pathways of tea-specific compounds. BMC Genom. 2011, 12. [CrossRef] [PubMed]

16. Wang, X.C.; Zhao, Q.Y.; Ma, C.L.; Zhang, Z.H.; Cao, H.L.; Kong, Y.M.; Yue, C.; Hao, X.Y.; Chen, L.; Ma, J.Q.; et al. Global transcriptome profiles of Camellia sinensis during cold acclimation. BMC Genom. 2013, 14. [CrossRef] [PubMed]

17. Wu, Z.J.; Li, X.H.; Liu, Z.W.; Li, H.; Wang, Y.X.; Zhuang, J. Transcriptome-based discovery of ap2/erf transcription factors related to temperature stress in tea plant (Camellia sinensis). Funct. Integr. Genom. 2015, 15, 741-752. [CrossRef] [PubMed]

18. Wu, Z.J.; Li, X.H.; Liu, Z.W.; Li, H.; Wang, Y.X.; Zhuang, J. Transcriptome-wide identification of Camellia sinensis WRKY transcription factors in response to temperature stress. Mol. Genet. Genom. 2016, 291, 255-269. [CrossRef] [PubMed]

19. Li, Q.; Lei, S.; Du, K.; Li, L.; Pang, X.; Wang, Z.; Wei, M.; Fu, S.; Hu, L.; Xu, L. RNA-seq based transcriptomic analysis uncovers $\alpha$-linolenic acid and jasmonic acid biosynthesis pathways respond to cold acclimation in Camellia japonica. Sci. Rep. 2016, 6, 36463. [CrossRef] [PubMed]

20. Zhang, Q.; Cai, M.; Yu, X.; Wang, L.; Guo, C.; Ming, R.; Zhang, J. Transcriptome dynamics of Camellia sinensis in response to continuous salinity and drought stress. Tree Genet. Genomes 2017, 13. [CrossRef]

21. Jin, X.; Liu, D.; Ma, L.; Gong, Z.; Cao, D.; Liu, Y.; Li, Y.; Jiang, C. Transcriptome and expression profiling analysis of recalcitrant tea (Camellia sinensis L.) seeds sensitive to dehydration. Int. J. Genom. 2018, 2018. [CrossRef] [PubMed]

22. Li, W.; Xiang, F.; Zhong, M.; Zhou, L.; Liu, H.; Li, S.; Wang, X. Transcriptome and metabolite analysis identifies nitrogen utilization genes in tea plant (Camellia sinensis). Sci. Rep. 2017, 7, 1693. [CrossRef] [PubMed]

23. Pan, J.; Wang, W.; Li, D.; Shu, Z.; Ye, X.; Chang, P.; Wang, Y. Gene expression profile indicates involvement of no in Camellia sinensis pollen tube growth at low temperature. BMC Genom. 2016, 17. [CrossRef] [PubMed]

24. Jayaswall, K.; Mahajan, P.; Singh, G.; Parmar, R.; Seth, R.; Raina, A.; Swarnkar, M.K.; Singh, A.K.; Shankar, R.; Sharma, R.K. Transcriptome analysis reveals candidate genes involved in Blister Blight defense in tea (Camellia sinensis (L) kuntze). Sci. Rep. 2016, 6, 30412. [CrossRef] [PubMed]

25. Wang, Y.N.; Tang, L.; Hou, Y.; Wang, P.; Yang, H.; Wei, C.L. Differential transcriptome analysis of leaves of tea plant (Camellia sinensis) provides comprehensive insights into the defense responses to Ectropis oblique attack using rna-seq. Funct. Integr. Genom. 2016, 16, 383-398. [CrossRef] [PubMed] 
26. Li, C.F.; Zhu, Y.; Yu, Y.; Zhao, Q.Y.; Wang, S.J.; Wang, X.C.; Yao, M.Z.; Luo, D.; Li, X.; Chen, L.; et al. Global transcriptome and gene regulation network for secondary metabolite biosynthesis of tea plant (Camellia sinensis). BMC Genom. 2015, 16. [CrossRef] [PubMed]

27. Zhang, H.B.; Xia, E.H.; Huang, H.; Jiang, J.J.; Liu, B.Y.; Gao, L.Z. De novo transcriptome assembly of the wild relative of tea tree (Camellia taliensis) and comparative analysis with tea transcriptome identified putative genes associated with tea quality and stress response. BMC Genom. 2015, 16. [CrossRef] [PubMed]

28. Wang, W.; Zhou, Y.; Wu, Y.; Dai, X.; Liu, Y.; Qian, Y.; Li, M.; Jiang, X.; Wang, Y.; Gao, L.; et al. An insight into catechins metabolic pathways of Camellia sinensis based on genome and transcriptome analysis. J. Agric. Food Chem. 2018, 66, 4281-4293. [CrossRef] [PubMed]

29. Wu, Z.J.; Li, X.H.; Liu, Z.W.; Xu, Z.S.; Zhuang, J. De novo assembly and transcriptome characterization: Novel insights into catechins biosynthesis in Camellia sinensis. BMC Plant Biol. 2014, 14. [CrossRef] [PubMed]

30. Li, J.; Lv, X.; Wang, L.; Qiu, Z.; Song, X.; Lin, J.; Chen, W. Transcriptome analysis reveals the accumulation mechanism of anthocyanins in 'Zijuan' tea (Camellia sinensis var. asssamica (Masters) kitamura) leaves. Plant Growth Regul. 2017, 81, 51-61. [CrossRef]

31. Zhou, X.; Li, J.; Zhu, Y.; Ni, S.; Chen, J.; Feng, X.; Zhang, Y.; Li, S.; Zhu, H.; Wen, Y. De novo assembly of the Camellia nitidissima transcriptome reveals key genes of flower pigment biosynthesis. Front Plant Sci. 2017, 8. [CrossRef] [PubMed]

32. Li, X.; Fan, Z.; Guo, H.; Ye, N.; Lyu, T.; Yang, W.; Wang, J.; Wang, J.T.; Wu, B.; Li, J.; et al. Comparative genomics analysis reveals gene family expansion and changes of expression patterns associated with natural adaptations of flowering time and secondary metabolism in yellow Camellia. Funct. Integr. Genom. 2018. [CrossRef] [PubMed]

33. Li, X.; Li, J.; Fan, Z.; Liu, Z.; Tanaka, T.; Yin, H. Global gene expression defines faded whorl specification of double flower domestication in Camellia. Sci. Rep. 2017, 7, 3197. [CrossRef] [PubMed]

34. Yin, H.; Fan, Z.; Li, X.; Wang, J.; Liu, W.; Wu, B.; Ying, Z.; Liu, L.; Liu, Z.; Li, J. Phylogenetic tree-informed micrornaome analysis uncovers conserved and lineage-specific miRNAs in Camellia during floral organ development. J. Exp. Bot. 2016, 67, 2641-2653. [CrossRef] [PubMed]

35. Hao, X.; Yang, Y.; Yue, C.; Wang, L.; Horvath, D.P.; Wang, X. Comprehensive transcriptome analyses reveal differential gene expression profiles of Camellia sinensis axillary buds at para-, endo-, ecodormancy, and bud flush stages. Front. Plant Sci. 2017, 8. [CrossRef] [PubMed]

36. Thirugnanasambantham, K.; Prabu, G.; Palanisamy, S.; Chandrabose, S.R.; Mandal, A.K. Analysis of dormant bud (Banjhi) specific transcriptome of tea (Camellia sinensis (L.) o. Kuntze) from cDNA library revealed dormancy-related genes. Appl. Biochem. Biotechnol. 2013, 169, 1405-1417. [CrossRef] [PubMed]

37. Fan, Z.; Li, J.; Li, X.; Wu, B.; Wang, J.; Liu, Z.; Yin, H. Genome-wide transcriptome profiling provides insights into floral bud development of summer-flowering Camellia azalea. Sci. Rep. 2015, 5, 9729. [CrossRef] [PubMed]

38. Liu, F.; Wang, Y.; Ding, Z.; Zhao, L.; Xiao, J.; Wang, L.; Ding, S. Transcriptomic analysis of flower development in tea (Camellia sinensis (L.)). Gene 2017, 631, 39-51. [CrossRef] [PubMed]

39. Paul, A.; Jha, A.; Bhardwaj, S.; Singh, S.; Shankar, R.; Kumar, S. RNA-seq-mediated transcriptome analysis of actively growing and winter dormant shoots identifies non-deciduous habit of evergreen tree tea during winters. Sci. Rep. 2014, 4, 5932. [CrossRef] [PubMed]

40. Wu, Q.; Chen, Z.; Sun, W.; Deng, T.; Chen, M. De novo sequencing of the leaf transcriptome reveals complex light-responsive regulatory networks in Camellia sinensis cv. Baijiguan. Front. Plant. Sci. 2016, 7. [CrossRef] [PubMed]

41. Wei, K.; Wang, L.; Cheng, H.; Zhang, C.; Ma, C.; Zhang, L.; Gong, W.; Wu, L. Identification of genes involved in indole-3-butyric acid-induced adventitious root formation in nodal cuttings of Camellia sinensis (L.) by suppression subtractive hybridization. Gene 2013, 514, 91-98. [CrossRef] [PubMed]

42. Wei, K.; Wang, L.Y.; Wu, L.Y.; Zhang, C.C.; Li, H.L.; Tan, L.Q.; Cao, H.L.; Cheng, H. Transcriptome analysis of indole-3-butyric acid-induced adventitious root formation in nodal cuttings of Camellia sinensis (L.). PLoS ONE 2014, 9. [CrossRef] [PubMed]

43. Xia, E.H.; Jiang, J.J.; Huang, H.; Zhang, L.P.; Zhang, H.B.; Gao, L.Z. Transcriptome analysis of the oil-rich tea plant, Camellia oleifera, reveals candidate genes related to lipid metabolism. PLoS ONE 2014, 9. [CrossRef] [PubMed] 
44. Dong, B.; Wu, B.; Hong, W.; Li, X.; Li, Z.; Xue, L.; Huang, Y. Transcriptome analysis of the tea oil Camellia (Camellia oleifera) reveals candidate drought stress genes. PLoS ONE 2017, 12. [CrossRef] [PubMed]

45. Lin, P.; Wang, K.; Zhou, C.; Xie, Y.; Yao, X.; Yin, H. Seed transcriptomics analysis in Camellia oleifera uncovers genes associated with oil content and fatty acid composition. Int. J. Mol. Sci. 2018, 19, 118. [CrossRef] [PubMed]

46. Chen, J.; Yang, X.; Huang, X.; Duan, S.; Long, C.; Chen, J.; Rong, J. Leaf transcriptome analysis of a subtropical evergreen broadleaf plant, wild oil-tea camellia (Camellia oleifera), revealing candidate genes for cold acclimation. BMC Genom. 2017, 18. [CrossRef] [PubMed]

47. Wang, Z.W.; Jiang, C.; Wen, Q.; Wang, N.; Tao, Y.Y.; Xu, L.A. Deep sequencing of the Camellia chekiangoleosa transcriptome revealed candidate genes for anthocyanin biosynthesis. Gene 2014, 538, 1-7. [CrossRef] [PubMed]

48. Feng, J.L.; Yang, Z.J.; Bai, W.W.; Chen, S.P.; Xu, W.Q.; El-Kassaby, Y.A.; Chen, H. Transcriptome comparative analysis of two Camellia species reveals lipid metabolism during mature seed natural drying. Trees 2017, 31, 1827-1848. [CrossRef]

49. Jiang, C.; Wen, Q.; Chen, Y.; Xu, L.; Huang, M. Efficient extraction of RNA from various Camellia species rich in secondary metabolites for deep transcriptome sequencing and gene expression analysis. Afr. J. Biotechnol. 2011, 10, 16769-16773. [CrossRef]

50. Wu, H.; Chen, D.; Li, J.; Yu, B.; Qiao, X.; Huang, H.; He, Y. De novo characterization of leaf transcriptome using 454 sequencing and development of EST-SSR markers in tea (Camellia sinensis). Plant Mol. Biol. Rep. 2013, 31, 524-538. [CrossRef]

51. Tan, L.Q.; Wang, L.Y.; Wei, K.; Zhang, C.C.; Wu, L.Y.; Qi, G.N.; Cheng, H.; Zhang, Q.; Cui, Q.M.; Liang, J.B. Floral transcriptome sequencing for SSR marker development and linkage map construction in the tea plant (Camellia sinensis). PLoS ONE 2013, 8. [CrossRef] [PubMed]

52. Liufu, Y.Q.; Peng, G.Q.; Lu, Y.B.; Ye, Q.Q.; Tang, S.Q. Development and characterization of 38 microsatellite markers for Camellia flavida based on transcriptome sequencing. Conserv. Genet. Resour. 2014, 6, 1007-1010. [CrossRef]

53. Jia, B.; Lin, Q.; Lin, Z.; Tan, X.; Lei, X.; Hu, X.; Shao, F. Development of 15 genic-SSR markers in oil-tea tree (Camellia oleifera) based on transcriptome sequencing. Genetika 2014, 46, 789-797. [CrossRef]

54. Arbona, V.; Manzi, M.; Ollas, C.; Gomez-Cadenas, A. Metabolomics as a tool to investigate abiotic stress tolerance in plants. Int. J. Mol. Sci. 2013, 14, 4885-4911. [CrossRef] [PubMed]

55. Arasimowicz, M.; Floryszak-Wieczorek, J. Nitric oxide as a bioactive signalling molecule in plant stress responses. Plant Sci. 2007, 172, 876-887. [CrossRef]

56. Guo, Z.; Tan, J.; Zhuo, C.; Wang, C.; Xiang, B.; Wang, Z. Abscisic acid, $\mathrm{H}_{2} \mathrm{O}_{2}$ and nitric oxide interactions mediated cold-induced S-adenosylmethionine synthetase in Medicago sativa subsp. Falcata that confers cold tolerance through up-regulating polyamine oxidation. Plant Biotechnol. J. 2014, 12, 601-612. [CrossRef] [PubMed]

57. Zhao, M.G.; Chen, L.; Zhang, L.L.; Zhang, W.H. Nitric reductase-dependent nitric oxide production is involved in cold acclimation and freezing tolerance in Arabidopsis. Plant Physiol. 2009, 151, 755-767. [CrossRef] [PubMed]

58. Guo, C.; Gao, X.B.; Lian, H.E.; Zhang, Q.; Meng, Z.H.; Zhao-Yun, L.; Chen, J. Application research progress of biological control of tea diseases and pests. Guangdong Agric. Sci. 2014, 41, 105-109.

59. Tang, Y.; Zhou, G.; He, L.I.; Zhong, W.; Gong, H.; Wang, L. Identification of a new anthracnose of Camellia oleifera based on multiple-gene phylogeny. Chin. J. Trop. Crops 2015, 36, 972-977.

60. Chang, M.S.; Deng, Y.; Liao, W.J.; Quan, S.U.; Fang, X.Y.; Yao-Jun, W.U. Study on the relationship between enzyme activity and disease resistance of different Camellia oleifera varieties to Colletotrichum gloeosporioides penz. For. Res. 2018, 31, 141-146.

61. Korte, A.; Farlow, A. The advantages and limitations of trait analysis with GWAS: A review. Plant Methods 2013, 9. [CrossRef] [PubMed]

62. Collard, B.C.Y.; Mackill, D.J. Marker-assisted selection: An approach for precision plant breeding in the twenty-first century. Philos. Trans. R. Soc. London B. Biol. Sci. 2008, 363, 557-572. [CrossRef] [PubMed]

63. Yousef, G.G.; Juvik, J.A. Comparison of phenotypic and marker-assisted selection for quantitative traits in sweet corn. Crop Sci. 2001, 41, 645-655. [CrossRef] 
64. Flachowsky, H.; Roux, P.M.L.; Peil, A.; Patocchi, A.; Richter, K.; Hanke, M.V. Application of a high-speed breeding technology to apple (malus $\times$ domestica) based on transgenic early flowering plants and marker-assisted selection. New Phytol. 2011, 192, 364-377. [CrossRef] [PubMed]

65. Gupta, P.K.; Langridge, P.; Mir, R.R. Marker-assisted wheat breeding: Present status and future possibilities. Mol. Breed. 2010, 26, 145-161. [CrossRef]

66. Castro, A.J.; Capettini, F.; Corey, A.E.; Filichkina, T.; Hayes, P.M.; Kleinhofs, A.; Kudrna, D.; Richardson, K.; Sandoval-Islas, S.; Rossi, C.; et al. Mapping and pyramiding of qualitative and quantitative resistance to stripe rust in barley. Theor. Appl. Genet. 2003, 107, 922-930. [CrossRef] [PubMed]

67. Bali, S.; Mamgain, A.; Raina, S.N.; Yadava, S.K.; Bhat, V.; Das, S.; Pradhan, A.K.; Goel, S. Construction of a genetic linkage map and mapping of drought tolerance trait in Indian beveragial tea. Mol. Breed. 2015, 35. [CrossRef]

68. Devi, A.M.; Goel, S.; Misra, A.K. Generation of silver stained TE-AFLP markers in tea (Camellia sinensis) and their assessment in filling gaps with construction of a genetic linkage map. Sci. Horti. 2015, 192, $293-301$. [CrossRef]

69. Hackett, C.A.; Wachira, F.N.; Paul, S.; Powell, W.; Waugh, R. Construction of a genetic linkage map for Camellia sinensis (tea). Heredity 2010, 85, 346-355. [CrossRef]

70. Hu, C.Y.; Lee, T.C.; Tsai, H.T.; Tsai, Y.Z.; Lin, S.F. Construction of an integrated genetic map based on maternal and paternal lineages of tea (Camellia sinensis). Euphytica 2013, 191, 141-152. [CrossRef]

71. Huang, F.P.; Liang, Y.R.; Jian-Lian, L.U.; Chen, R.B. Genetic mapping of first generation of backcross in tea by RAPD and ISSR markers. J. Tea Sci. 2006, 26, 171-176.

72. Huang, J.A.; Jia-Xian, L.I.; Huang, Y.H.; Luo, J.W.; Gong, Z.H.; Liu, Z.H. Construction of AFLP molecular markers linkage map in tea plant. J. Tea Sci. 2005, 25, 7-15.

73. Kamunya, S.M.; Wachira, F.N.; Pathak, R.S.; Korir, R.; Sharma, V.; Kumar, R.; Bhardwaj, P.; Chalo, R.; Ahuja, P.S.; Sharma, R.K. Genomic mapping and testing for quantitative trait loci in tea (Camellia sinensis (L.) o. Kuntze). Tree Genet. Genomes 2010, 6, 915-929. [CrossRef]

74. Ma, J.Q.; Huang, L.; Ma, C.L.; Jin, J.Q.; Li, C.F.; Wang, R.K.; Zheng, H.K.; Yao, M.Z.; Chen, L. Large-scale SNP discovery and genotyping for constructing a high-density genetic map of tea plant using specific-locus amplified fragment sequencing (SLAF-seq). PLoS ONE 2015, 10. [CrossRef] [PubMed]

75. Ma, J.Q.; Yao, M.Z.; Ma, C.L.; Wang, X.C.; Jin, J.Q.; Wang, X.M.; Chen, L. Construction of a SSR-based genetic map and identification of QTLs for catechins content in tea plant (Camellia sinensis). PLoS ONE 2014, 9. [CrossRef] [PubMed]

76. Fumiya, T.; Kazumi, F.; Sakura, O.M.; Nobuo, Y.; Tomomi, U.; Izumi, K.; Hiroyuki, F.; Junichi, T. Construction of a high-density reference linkage map of tea (Camellia sinensis). Breed. Sci. 2012, 62, 263-273.

77. Tan, L.Q.; Wang, L.Y.; Xu, L.Y.; Wu, L.Y.; Peng, M.; Zhang, C.C.; Wei, K.; Bai, P.X.; Li, H.L.; Cheng, H.; et al. SSR-based genetic mapping and QTL analysis for timing of spring bud flush, young shoot color, and mature leaf size in tea plant (Camellia sinensis). Tree Genet. Genomes 2016, 12. [CrossRef]

78. Borevitz, J.O.; Nordborg, M. Update on genomics and natural variation in Arabidopsis. The impact of genomics on the study of natural variation in Arabidopsis. Plant Physiol. 2003, 132, 718-725. [CrossRef] [PubMed]

79. Han, B.; Huang, X. Sequencing-based genome-wide association study in rice. Curr. Opin. Plant Biol. 2013, 16, 133-138. [CrossRef] [PubMed]

80. Huang, X.; Feng, Q.; Qian, Q.; Zhao, Q.; Wang, L.; Wang, A.; Guan, J.; Fan, D.; Weng, Q.; Huang, T.; et al. High-throughput genotyping by whole-genome resequencing. Genome Res. 2009, 19. [CrossRef] [PubMed]

81. Xie, W.; Feng, Q.; Yu, H.; Huang, X.; Zhao, Q.; Xing, Y.; Yu, S.; Han, B.; Zhang, Q. Parent-independent genotyping for constructing an ultrahigh-density linkage map based on population sequencing. Proc. Natl. Acad. Sci. USA 2010, 107, 10578-10583. [CrossRef] [PubMed]

82. Hirschhorn, J.N.; Daly, M.J. Genome-wide association studies for common diseases and complex traits. Nat. Rev. Genet. 2005, 6, 95-108. [CrossRef] [PubMed]

83. Atwell, S.; Huang, Y.S.; Vilhjálmsson, B.J.; Willems, G.; Horton, M.; Li, Y.; Meng, D.Z.; Platt, A.; Tarone, A.M.; $\mathrm{Hu}, \mathrm{T} . \mathrm{T}$; et al. Genome-wide association study of 107 phenotypes in Arabidopsis thaliana inbred lines. Nature 2010, 465, 627-631. [CrossRef] [PubMed] 
84. Huang, X.; Wei, X.; Sang, T.; Zhao, Q.; Feng, Q.; Zhao, Y.; Li, C.; Zhu, C.; Lu, T.; Zhang, Z.; et al. Genome-wide association studies of 14 agronomic traits in rice landraces. Nat. Genet. 2010, 42, 961-967. [CrossRef] [PubMed]

85. Huang, X.; Zhao, Y.; Wei, X.; Li, C.; Wang, A.; Zhao, Q.; Li, W.; Guo, Y.; Deng, L.; Zhu, C.; et al. Genome-wide association study of flowering time and grain yield traits in a worldwide collection of rice germplasm. Nat. Genet. 2011, 44, 32-39. [CrossRef] [PubMed]

86. Zhou, Z.; Jiang, Y.; Wang, Z.; Gou, Z.; Lyu, J.; Li, W.; Yu, Y.; Shu, L.; Zhao, Y.; Ma, Y.; et al. Resequencing 302 wild and cultivated accessions identifies genes related to domestication and improvement in soybean. Nat. Biotechnol. 2015, 33, 408-414. [CrossRef] [PubMed]

87. Jia, G.; Huang, X.; Zhi, H.; Zhao, Y.; Zhao, Q.; Li, W.; Chai, Y.; Yang, L.; Liu, K.; Lu, H.; et al. A haplotype map of genomic variations and genome-wide association studies of agronomic traits in foxtail millet (Setaria italica). Nat. Genet. 2013, 45, 957-961. [CrossRef] [PubMed]

88. Qi, J.; Liu, X.; Shen, D.; Miao, H.; Xie, B.; Li, X.; Zeng, P.; Wang, S.; Shang, Y.; Gu, X.; et al. A genomic variation map provides insights into the genetic basis of cucumber domestication and diversity. Nat. Genet. 2013, 45, 1510-1515. [CrossRef] [PubMed]

89. Lin, T.; Zhu, G.; Zhang, J.; Xu, X.; Yu, Q.; Zheng, Z.; Zhang, Z.; Lun, Y.; Li, S.; Wang, X.; et al. Genomic analyses provide insights into the history of tomato breeding. Nat. Genet. 2014, 46, 1220-1226. [CrossRef] [PubMed]

90. Fang, L.; Wang, Q.; Hu, Y.; Jia, Y.; Chen, J.; Liu, B.; Zhang, Z.; Guan, X.; Chen, S.; Zhou, B.; et al. Genomic analyses in cotton identify signatures of selection and loci associated with fiber quality and yield traits. Nat. Genet. 2017, 49, 1089-1098. [CrossRef] [PubMed]

91. Du, X.; Huang, G.; He, S.; Yang, Z.; Sun, G.; Ma, X.; Li, N.; Zhang, X.; Sun, J.; Liu, M.; et al. Resequencing of 243 diploid cotton accessions based on an updated A genome identifies the genetic basis of key agronomic traits. Nat. Genet. 2018, 50, 796-802. [CrossRef] [PubMed]

92. Evans, L.M.; Slavov, G.T.; Rodgers-Melnick, E.; Martin, J.; Ranjan, P.; Muchero, W.; Brunner, A.M.; Schackwitz, W.; Gunter, L.; Chen, J.G.; et al. Population genomics of Populus trichocarpa identifies signatures of selection and adaptive trait associations. Nat. Genet. 2014, 46, 1089-1096. [CrossRef] [PubMed]

93. Kang, H.M.; Sul, J.H.; Service, S.K.; Zaitlen, N.A.; Kong, S.Y.; Freimer, N.B.; Sabatti, C.; Eskin, E. Variance component model to account for sample structure in genome-wide association studies. Nat, Genet. 2010, 42, 348-354. [CrossRef] [PubMed]

94. Korte, A.; Vilhjálmsson, B.J.; Segura, V.; Platt, A.; Long, Q.; Nordborg, M. A mixed-model approach for genome-wide association studies of correlated traits in structured populations. Nat. Genet. 2012, 44, 1066-1071. [CrossRef] [PubMed]

95. Segura, V.; Vilhjálmsson, B.J.; Platt, A.; Korte, A.; Seren, Ü.; Long, Q.; Nordborg, M. An efficient multi-locus mixed-model approach for genome-wide association studies in structured populations. Nat. Genet. 2013, 44, 825-830. [CrossRef] [PubMed]

96. Yu, J.; Pressoir, G.; Briggs, W.H.; Vroh, B.I.; Yamasaki, M.; Doebley, J.F.; Mcmullen, M.D.; Gaut, B.S.; Nielsen, D.M.; Holland, J.B.; et al. A unified mixed-model method for association mapping that accounts for multiple levels of relatedness. Nat. Genet. 2006, 38, 203-208. [CrossRef] [PubMed]

97. Zhang, Z.; Ersoz, E.; Lai, C.Q.; Todhunter, R.J.; Tiwari, H.K.; Gore, M.A.; Bradbury, P.J.; Yu, J.; Arnett, D.K.; Ordovas, J.M.; et al. Mixed linear model approach adapted for genome-wide association studies. Nat. Genet. 2010, 42, 355-360. [CrossRef] [PubMed]

98. Cui, L.; Yao, S.; Dai, X.; Yin, Q.; Liu, Y.; Jiang, X.; Wu, Y.; Qian, Y.; Pang, Y.; Gao, L.; et al. Identification of UDP-glycosyltransferases involved in the biosynthesis of astringent taste compounds in tea (Camellia sinensis). J. Exp. Bot. 2016, 67, 2285-2297. [CrossRef] [PubMed]

99. Zhu, J.; Wang, X.; Guo, L.; Xu, Q.; Zhao, S.; Li, F.; Yan, X.; Liu, S.; Wei, C. Characterization and alternative splicing profiles of lipoxygenase gene family in tea plant (Camellia sinensis). Plant Cell Physiol. 2018, 59, 1765-1781. [CrossRef] [PubMed] 
100. Liu, S.; Han, B. Differential expression pattern of an acidic 9/13-lipoxygenase in flower opening and senescence and in leaf response to phloem feeders in the tea plant. BMC Plant Biol. 2010, 10. [CrossRef] [PubMed]

101. Sun, Y.K.; Fan, Z.Q.; Li, X.L.; Li, J.Y.; Yin, H.F. The APETALA1 and FRUITFUL homologs in Camellia japonica and their roles in double flower domestication. Mol. Breed. 2014, 33, 821-834. [CrossRef]

102. Sun, Y.; Fan, Z.; Li, X.; Liu, Z.; Li, J.; Yin, H. Distinct double flower varieties in Camellia japonica exhibit both expansion and contraction of C-class gene expression. BMC Plant Biol. 2014, 14. [CrossRef] [PubMed]

103. Liljegren, S.J.; Ditta, G.S.; Eshed, Y.; Savidge, B.; Bowman, J.L.; Yanofsky, M.F. SHATTERPROOF MADS-box genes control seed dispersal in Arabidopsis. Nature 2000, 404, 766-770. [CrossRef] [PubMed]

104. Powell, A.L.; Nguyen, C.V.; Hill, T.; Cheng, K.L.; Figueroa-Balderas, R.; Aktas, H.; Ashrafi, H.; Pons, C.; Fernandez-Munoz, R.; Vicente, A.; et al. Uniform ripening encodes a golden 2-like transcription factor regulating tomato fruit chloroplast development. Science 2012, 336, 1711-1715. [CrossRef] [PubMed]

105. Vrebalov, J.; Ruezinsky, D.; Padmanabhan, V.; White, R.; Medrano, D.; Drake, R.; Schuch, W.; Giovannoni, J. A MADS-box gene necessary for fruit ripening at the tomato Ripening-inhibitor (Rin) locus. Science 2002, 296, 343-346. [CrossRef] [PubMed]

106. Dardick, C.; Callahan, A.M. Evolution of the fruit endocarp: Molecular mechanisms underlying adaptations in seed protection and dispersal strategies. Front. Plant Sci. 2014, 5. [CrossRef] [PubMed]

107. Pabon-Mora, N.; Wong, G.K.; Ambrose, B.A. Evolution of fruit development genes in flowering plants. Front. Plant Sci. 2014, 5. [CrossRef]

108. Liu, J.H.; Xu, B.Y.; Zhang, J.; Jin, Z.Q. The interaction of MADS-box transcription factors and manipulating fruit development and ripening. Hereditas 2010, 32, 893-902. [PubMed]

109. Ferrandiz, C.; Fourquin, C. Role of the FUL-SHP network in the evolution of fruit morphology and function. J. Exp. Bot. 2014, 65, 4505-4513. [CrossRef] [PubMed]

110. Bemer, M.; Karlova, R.; Ballester, A.R.; Tikunov, Y.M.; Bovy, A.G.; Wolters-Arts, M.; Rossetto Pde, B.; Angenent, G.C.; de Maagd, R.A. The tomato FRUITFULL homologs TDR4/FUL1 and MBP7/FUL2 regulate ethylene-independent aspects of fruit ripening. Plant Cell 2012, 24, 4437-4451. [CrossRef] [PubMed]

111. Albert, N.W.; Lewis, D.H.; Zhang, H.; Irving, L.J.; Jameson, P.E.; Davies, K.M. Light-induced vegetative anthocyanin pigmentation in Petunia. J. Exp. Bot. 2009, 60, 2191-2202. [CrossRef] [PubMed]

112. Groszmann, M.; Paicu, T.; Alvarez, J.P.; Swain, S.M.; Smyth, D.R. SPATULA and ALCATRAZ, are partially redundant, functionally diverging bHLH genes required for Arabidopsis gynoecium and fruit development. Plant J. 2011, 68, 816-829. [CrossRef] [PubMed]

113. Rajani, S.; Sundaresan, V. The Arabidopsis myc/bHLH gene ALCATRAZ enables cell separation in fruit dehiscence. Curr. Biol. 2001, 11, 1914-1922. [CrossRef]

114. Mitsuda, N.; Iwase, A.; Yamamoto, H.; Yoshida, M.; Seki, M.; Shinozaki, K.; Ohme-Takagi, M. NAC transcription factors, NST1 and NST3, are key regulators of the formation of secondary walls in woody tissues of Arabidopsis. Plant Cell 2007, 19, 270-280. [CrossRef] [PubMed]

115. Shan, W.; Kuang, J.F.; Chen, L.; Xie, H.; Peng, H.H.; Xiao, Y.Y.; Li, X.P.; Chen, W.X.; He, Q.G.; Chen, J.Y.; et al. Molecular characterization of banana NAC transcription factors and their interactions with ethylene signalling component EIL during fruit ripening. J. Exp. Bot. 2012, 63, 5171-5187. [CrossRef] [PubMed]

116. Machemer, K.; Shaiman, O.; Salts, Y.; Shabtai, S.; Sobolev, I.; Belausov, E.; Grotewold, E.; Barg, R. Interplay of MYB factors in differential cell expansion, and consequences for tomato fruit development. Plant J. 2011, 68, 337-350. [CrossRef] [PubMed]

117. Vrebalov, J.; Pan, I.L.; Arroyo, A.J.; McQuinn, R.; Chung, M.; Poole, M.; Rose, J.; Seymour, G.; Grandillo, S.; Giovannoni, J.; et al. Fleshy fruit expansion and ripening are regulated by the tomato SHATTERPROOF gene TAGL 1 . Plant Cell 2009, 21, 3041-3062. [CrossRef] [PubMed]

118. Garceau, D.C.; Batson, M.K.; Pan, I.L. Variations on a theme in fruit development: The PLE lineage of MADS-box genes in tomato (TAGL 1 ) and other species. Planta 2017, 246, 313-321. [CrossRef] [PubMed]

119. Pan, I.L.; McQuinn, R.; Giovannoni, J.J.; Irish, V.F. Functional diversification of agamous lineage genes in regulating tomato flower and fruit development. J. Exp. Bot. 2010, 61, 1795-1806. [CrossRef] [PubMed] 
120. Li, H.; Huang, W.; Liu, Z.W.; Wang, Y.X.; Zhuang, J. Transcriptome-based analysis of Dof family transcription factors and their responses to abiotic stress in tea plant (Camellia sinensis). Int. J. Genom. 2016, 2016. [CrossRef] [PubMed]

121. Wang, L.; Cao, H.; Qian, W.; Yao, L.; Hao, X.; Li, N.; Yang, Y.; Wang, X. Identification of a novel bZIP transcription factor in Camellia sinensis as a negative regulator of freezing tolerance in transgenic Arabidopsis. Ann. Bot. 2017, 119, 1195-1209. [CrossRef] [PubMed]

122. Wang, M.; Zhuang, J.; Zou, Z.; Li, Q.; Xin, H.; Li, X. Overexpression of a Camellia sinensis DREB transcription factor gene $(C S D R E B)$ increases salt and drought tolerance in transgenic Arabidopsis thaliana. J. Plant Biol. 2017, 60, 452-461. [CrossRef]

(C) 2018 by the authors. Licensee MDPI, Basel, Switzerland. This article is an open access article distributed under the terms and conditions of the Creative Commons Attribution (CC BY) license (http:/ / creativecommons.org/licenses/by/4.0/). 